\title{
Peripheral joint ankylosis in the spontaneous model of arthritis in DBA/1 mice is genetically associated with BMP signaling
}

\author{
S Carter ${ }^{1 *}$, I Derese ${ }^{1}$, K Braem $^{1}$, AM Valdes ${ }^{2}$, FP Luyten ${ }^{1}$, RJ Lories $^{1}$ \\ From 18th Pediatric Rheumatology European Society (PReS) Congress \\ Bruges, Belgium. 14-18 September 2011
}

Progression of ankylosis in patients with ankylosing spondylitis is highly variable. This suggests that ankylosis is at least partially due to genetic factors. We used the ankylosing enthesits model in DBA/1 mice to search for associated genes.

Male DBA/1 were crossed with female BALB/c mice. Male F2 mice from different litters were studied by histomorphology at 26 weeks. 159 markers with sequencelength polymorphisms on the autosomes were selected. Median spacing between the markers was 6.9 cM. 162 F2 male mice were studied. Genes in regions of interests were linked to skeletal development, bone morphogenetic protein (BMP) and Wnt signaling pathways with the Gene Ontology database. The association was evaluated by Chi-square tests with a False Discovery Rate (FDR) algorithm.

Incidence of ankylosing enthesitis was lower in the F2 generation as compared to wild-type DBA/1 males (42\% vs. $72 \% ; \mathrm{p}<0.0001$ ). When applying the FDR algorithm for 159 markers, associations with D3MIT199 and D3MIT160 were significant $(\mathrm{p}<0.016)$. Adjacent markers were additionally genotyped. In the associated region between markers D3MIT42 and D3MIT129, 162 genes were found among which Bmpr1b, Cxxc4, Lef1, Papss1, Pitx2, and Ube2d3. Only BMP receptor type $1 \mathrm{~b}(B M P r 1 b)$ was specifically upregulated in mice with spontaneous arthritis as demonstrated by quantitative RT-PCR.

By using F2 mouse genetics in the analysis of ankylosis, we identified a locus on chromosome 3 that shows association. Within this locus, several genes could play a role in ankylosis but the expression profile suggests that

\footnotetext{
* Correspondence: shea.carter@med.kuleuven.be

'Laboratory for Skeletal Development and Joint Disorders, Division of Rheumatology, KU Leuven, Belgium

Full list of author information is available at the end of the article
}

BMP receptor $1 \mathrm{~b}$ is involved, further supporting a critical role for BMPs in this process.

\begin{abstract}
Author details
'Laboratory for Skeletal Development and Joint Disorders, Division of Rheumatology, KU Leuven, Belgium. ${ }^{2}$ Department of Twin Research and Genetic Epidemiology, Kings College London, London, UK.
\end{abstract}

Published: 14 September 2011

doi:10.1186/1546-0096-9-S1-P314

Cite this article as: Carter et al:: Peripheral joint ankylosis in the spontaneous model of arthritis in DBA/1 mice is genetically associated with BMP signaling. Pediatric Rheumatology 2011 9(Suppl 1):P314.

\section{Submit your next manuscript to BioMed Central and take full advantage of: \\ - Convenient online submission \\ - Thorough peer review \\ - No space constraints or color figure charges \\ - Immediate publication on acceptance \\ - Inclusion in PubMed, CAS, Scopus and Google Scholar \\ - Research which is freely available for redistribution \\ Submit your manuscript at www.biomedcentral.com/submit}

